Review

\title{
Sustainability of US Organic Beef and Dairy Production Systems: Soil, Plant and Cattle Interactions
}

\author{
Aimee N. Hafla ${ }^{1}$, Jennifer W. MacAdam ${ }^{2, *}$ and Kathy J. Soder ${ }^{1}$ \\ 1 United States Department of Agriculture ${ }^{\dagger}$, Agriculture Research Service, Pasture Systems and \\ Watershed Management Research Unit, Building 3702, Curtin Road, University Park, PA 16802, USA; \\ E-Mails: kathy.soder@ars.usda.gov (K.J.S.); aimee.hafla@ars.usda.gov (A.N.H.) \\ 2 Utah State University, Department of Plants, Soils and Climate, 4820 Old Main Hill, Logan 84322, \\ UT, USA \\ $\dagger$ USDA is an equal opportunity provider and employer. \\ * Author to whom correspondence should be addressed; E-Mail: jennifer.macadam@usu.edu; \\ Tel.: +1-435-797-2364; Fax: 1-435-797-3376.
}

Received: 3 June 2013; in revised form: 28 June 2013 / Accepted: 4 July 2013 /

Published: 11 July 2013

Abstract: In 2010, the National Organic Program implemented a rule for the US stating
that pasture must be a significant source of feed in organic ruminant systems. This article
will focus on how the pasture rule has impacted the management, economics and
nutritional value of products derived from organic ruminant systems and the interactions of
grazing cattle with pasture forages and soils. The use of synthetic fertilizers is prohibited in
organic systems; therefore, producers must rely on animal manures, compost and cover
crops to increase and maintain soil nitrogen content. Rotational and strip grazing are two of
the most common grazing management practices utilized in grazing ruminant production
systems; however, these practices are not exclusive to organic livestock producers. For dairy
cattle, grazing reduces foot and leg problems common in confinement systems, but lowers milk
production and exposes cows to parasites that can be difficult to treat without pharmaceuticals.
Organic beef cattle may still be finished in feedlots for no more than 120 days in the US, but
without growth hormones and antibiotics, gains may be reduced and illnesses increased.
Grazing reduces the use of environmentally and economically costly concentrate feeds and
recycles nutrients back to the soil efficiently, but lowers the rate of beef liveweight gain.
Increased use of pasture can be economically, environmentally and socially sustainable if 
forage use efficiency is high and US consumers continue to pay a premium for organic beef and dairy products.

Keywords: organic agriculture; non-organic agriculture; organic pasture rule; dairy production; beef production; grass; legume; soil

\section{Introduction: Organic vs. Non-Organic Cattle Feeding Practices}

In the United States, organic agricultural systems differ from non-organic systems in many important ways, most notably in restrictions on the use of chemical fertilizers and pesticides in all organic farming systems, and in restrictions on the use of antibiotics, feed additives and growth hormones in organic animal systems. The availability and cost of certified organic feeds is a major challenge for US organic dairy and beef producers. In 2011, NASS estimated that 83,989,000 acres of corn were harvested in the US, with only 134,877 of those certified organic. So little organic corn and soybean production occurs that limited supply results in prices of certified organic feedstuffs that are two to three times greater compared to non-organically grown feeds [1]. The cost of organic supplements for energy and protein results in more on-farm production of these feeds in organic systems compared to typical non-organic systems. However, some farms are too small or have land that is undesirable for the production of annual crops and therefore may have to rely on purchasing these feeds. Moreover, availability of local organic feeds can be limited, adding transportation expenses to the cost of the feed. In 2011, the state of Iowa was the greatest producer of certified organic corn, while California had the greatest inventory of certified organic dairy and beef cattle [2]. Locally available by-product feeds resulting from grain processing, production of human foods and beverages and other manufacturing enterprises can provide livestock producers with lower cost feed supplements that provide protein and energy to support the growth and lactation of ruminant livestock. Some common by-product feeds utilized in non-organic dairy and feedlot rations include oil meals, bran, middlings, brewers grains, distillers grains and beet pulp [3]. However, the availability of by-products produced to meet the National Organic Program (NOP) certified organic standards are limited and therefore organic producers are unlikely to have access to these feedstuffs to reduce feed costs. In the 2011 Certified Organic Production Survey conducted by the USDA-NASS, the quantity and value of commodity crops, fruits, vegetables and livestock produced were summarized; however, no organically produced by-products appeared in the report.

\subsection{The Pasture Rule}

In 2010 the NOP implemented the "Pasture Rule," requiring that certified organic ruminant animals consume pasture during the grazing season in their geographic region [4]. More specifically, the rule requires that during the grazing season animals must obtain an average minimum of $30 \%$ of their dry matter intake (DMI) by grazing certified organic pasture or rangeland and must graze at least 120 days each year (not necessarily continuous). Ruminant livestock that are to be grain finished are exempt from the requirement of $30 \%$ DMI from pasture during the finishing period, but must have access to pasture; 
however, the finishing period is not to exceed one-fifth of the animal's total life or 120 days [4]. The intent of the pasture rule was to establish specific enforceable standards regarding access to pasture by ruminant livestock and to assure consumers of organic products that livestock are raised in pasture-based systems, which are considered more natural and humane than confinement systems. Previous to implementation of the pasture rule, organic producers of dairy and beef cattle were required to provide animals with access to pasture that was managed for feed value; however, no frequency or duration of grazing time or proportion of grazed forage in the diet was specified. The implementation of the pasture rule has leveled the playing field between small and large certified organic dairy and meat producers by increasing the use of grazing in all organic ruminant enterprises, diminishing the economies of scale for the very largest producers.

The organic food production sector continues to grow [5] but less than $2 \%$ of US dairy production is currently organic. While statistics on non-organic use of pasture for dairy production are difficult to document, smaller non-organic dairy producers in the upper Midwest and Northeast are the most likely to rely on pasture as feed [6]. In general, non-organic dairy production and beef finishing are predominantly confinement systems in the US while organic beef and dairy production rely more on pasture. As of 2011, there was approximately 1.6 million acres of certified organic pasture and rangeland on 3,499 farms in the United States [2]. This paper focuses on the implications of the use of pasture within the restrictions that apply to organic dairy and beef agricultural systems in the US.

\subsection{Dairy Feeding Practices}

While smaller scale non-organic dairies may use pasture as a significant part of their feed, the majority of non-organic dairy cows are fed a combination of supplemental protein and energy sources (purchased or homegrown) and homegrown conserved forages such as silage, haylage, and dry hay. Organic dairy farms, on the other hand, rely more on pasture during the grazing season $[7,8]$ with some supplemental feeds (energy and/or conserved forages) as needed. In a review by Benbrook [9], it was found that the overall reliance on pasture for all non-organic dairy farms in the US was 3\% of DMI, and that $75 \%$ of cows on non-organic farms did not rely on pasture for any part of the lactating cow diet. However, it is important to note that in much of the US, climatic conditions require the harvest and storage of feeds on organic dairy farms to supply animals during drought and winter months.

\subsection{Beef Feeding Practices}

While production practices vary across regions, most beef cattle intended for commercial beef production spend a majority of their lives on grasslands and are subsequently finished with grain in commercial feedlots. The greatest divergence between organic and non-organic beef feeding practices is therefore during the finishing phase. Approximately $80 \%$ of non-organically raised beef cattle in the US are finished using grain-based (usually corn) rations [10]. Conversely, in a survey of certified organic beef producers in the US, $83 \%$ reported that they raised cattle exclusively or predominantly on grass and hay until slaughter, while the remaining 17\% reported using a grain finishing system [11]. All feeds consumed by certified organic ruminants must comply with NOP standards; therefore, all grains and conserved forages must be $100 \%$ certified organic. Vitamins, trace minerals and feed additives that are not produced organically are allowed in the diets of organic livestock in trace 
amounts provided they are allowed under the National List of Allowed and Prohibited Substances [12]. Finally, growth promotants such as ionophores and hormones [13] and antimicrobials [14] that are commonly used in beef feedlot finishing are not allowed in organic beef finishing.

\section{Organic Pasture Management}

The USDA definition of pasture is land that is used for livestock grazing that is managed to provide feed value and maintain or improve soil, water, and vegetative resources [12]. More specifically, the goals for pastures managed for organic production of livestock are to build soil structure and fertility, manage pests ecologically, conserve and promote plant and animal biodiversity, and maximize forage quality and production. Because organic and pasture-based livestock producers must rely on pastures managed without chemical fertilizers or herbicides for milk production or live weight gain, they are likely to place greater emphasis on pasture management than non-organic producers.

Managed grazing is not exclusive to organic livestock producers; however, due to the pasture rule organic dairy producers are far more likely to use intensive grazing management practices than are non-organic dairy operations. Rotational grazing and strip grazing are ruminant management strategies common to both organic dairy and beef farms, in regions and seasons where environmental and forage conditions allow. Rotational stocking is a method that uses recurring periods of grazing and rest among three or more pastures [15]. Rotational stocking can ensure intake of high quality forage for livestock throughout the grazing season, distribute forage growth optimally over time, and lengthen the grazing season [16]. Strip stocking is a variation of rotational stocking that may employ annual crops such as cereal grains or summer annuals (e.g., triticale, Austrian winter pea, sorghum-sudangrass) that are cultivated for grazing. Animals progress across a field, allotted a specific amount of feed for a short time, controlling feed intake and optimizing feeding efficiency [15]. Rotational and strip grazing are two of the most common grazing management practices utilized in grazing ruminant production systems; however, there are many other specific management practices in use across various regions.

\subsection{Soil Fertility in Organic Agricultural Systems}

In a meta-review of soil and environmental quality studies conducted in New Zealand, Switzerland, and the Great Plains of the US, Condron et al. [17] determined that soil organic matter and soil biological activity were consistently higher in organic systems compared to non-organic systems. Soil structure, cation exchange capacity, respiration and the soil content of mineralizable nitrogen relative to organic carbon were higher in organically farmed New Zealand soils, as was the number of earthworms [18]. However, soil $\mathrm{pH}$ and the content of phosphorus and sulfur were lower. This is consistent with other studies cited by Condron et al. [17], such as Liebig and Doran [19] and Nguyen et al. [20], who demonstrated that the imbalance between outputs and inputs, which were minimal for phosphorus and sulfur in the organic systems evaluated, lead to deficiencies over time. Løes and Øgaard [21] studied the change in plant available phosphorus over time in organic systems, and determined that maintenance of soil phosphorus is essential for the long-term productivity of organic systems. Cornforth and Sinclair [22] demonstrated that in grazing systems, the higher the stocking rate, the greater the need for phosphorus inputs. Gosling and Shepherd [23] also demonstrated the depletion of another important nutrient, potassium, under long-term organic farming. Where long-term manuring has increased plant-available 
potassium to undesirably high levels, nutrient export from farms in the form of beef and dairy products will have a long-term benefit. In the northeastern US, where heavy manure application has occurred for decades, nutrients such as potassium (and even phosphorus) have built up to very high levels. It is not unusual for pastures in the Northeast to have potassium levels in excess of $3 \%$, high enough to cause milk fevers [24]. The time required for plants to access phosphorus mineralized from organic sources such as manure [25] and from allowed mineral sources [17] compared with synthetic phosphate fertilizers varies greatly, which means that long-term planning is required for the proper maintenance of soil fertility in organic production systems.

Since the use of synthetic fertilizers is prohibited in organic systems, producers must rely on animal manures, compost and cover crops to increase soil nitrogen content. Nitrogen is needed in large quantities and is often a limiting nutrient in organic pastures and crop fields. In non-organic systems this issue is addressed by the use of nitrate or ammonia fertilization. However, nitrogen in the nitrate $\left(\mathrm{NO}_{3}{ }^{-}\right)$form is not held by the soil and can leach below the root zone into groundwater, even when it is applied as split applications, two or three times within the growing season, to minimize application in excess of plant need, and nitrate is a serious contaminant of drinking water. Microbes can convert nitrogen into forms that volatilize from the soil; nitrogen volatilized as nitrous oxide $\left(\mathrm{N}_{2} \mathrm{O}\right)$ has 300 times the greenhouse gas effect of carbon dioxide $\left(\mathrm{CO}_{2}\right)$. A fundamental understanding among organic practitioners is that nutrients should be recycled within each farm and the transfer of nutrients, leading to depletion or excess across farm boundaries, should be minimized. Manure is one of the best sources of nitrogen available to organic producers; manure also contains approximately $90 \%$ water by weight, so it is challenging to transport or distribute. Therefore, manure is commonly disposed of by applying it to the soil. However, drylot dairies and feedlots import nutrients and must compost manure and/or export it to surrounding cropland. While cropping-based (e.g., hay, silage, and cereal grains) dairy feeding operations often import nutrients to the farm and distribute the resulting manure nutrients on nearby cropland two or more times per year, pasture-based livestock feeding returns nutrients to the pasture during grazing [26].

Pastured ruminants are an important conduit for the return of the nutrients that are not exported from the farm as beef or dairy products to pasture soils. Grazing-based ruminant production allows most of the nutrients from a pasture to be immediately recycled onto the same pasture, reducing the loss of volatile nutrients (e.g., ammonia, methane) from manure storage and compost piles and lagoons, and reducing the time and fuel required to mechanically spread manure solids onto cropland. However, the distribution of manure on pastures is uneven at best. The nitrogen in urine patches is sufficiently concentrated that nitrate may leach from pastures into groundwater, forage that is soiled by manure will be rejected for a period of time, and unincorporated manure solids are vulnerable to runoff. Of the macronutrients, calcium, phosphorus and magnesium are largely excreted in the feces, while potassium is largely secreted in urine. Sulfur secretion is variable, but more nitrogen is excreted in urine than in feces, although this is influenced by diet. The form of nitrogen found in urine is readily converted to a form that can be volatilized by an enzyme present in feces, while nitrogen is excreted in feces as organic matter, which is mineralized much more slowly by soil microbial activity [27]. The management of cattle on pastures can influence the distribution of manure nutrients; rotational stocking or other types of management-intensive grazing (MiG) such as strip grazing result in a more even distribution of nutrients than continuous grazing [28]. Under rotational stocking, reasonably well-distributed 
manure nutrients can contribute to a flush of soil microbial activity in pastures, particularly if pastures are irrigated following grazing, and nutrients can be extracted and utilized by growing forage plants during the rest period between grazing events. The grazing pressure exerted by higher stocking densities or co-grazing with other species can reduce rejection of forages adjacent to urine or dung patches.

Cederberg and Mattsson [29] modeled Swedish non-organic and organic dairy nutrient inputs and outputs, and determined that while there were nutrient surpluses generated by both systems, they were one-tenth as high for phosphorus and potassium, and one-third as high for nitrogen on organic dairies. The need for nitrogen fertilization can be reduced by including nitrogen-fixing legumes, but bloat-causing legumes such as the Trifolium (true) clovers are limited to no more than 50\% of mixtures. Benbrook [9] estimated that in 2008, due to the organic dairy industry alone, 40 million pounds of synthetic nitrogen was not applied to land designated for certified organic use. Integrating livestock and cropping enterprises on a single farm not only spreads economic risk, but can improve the efficiency of nutrient cycling. Mixed crop-livestock systems such as dairies that grow their own conserved feed for winter, have been shown to minimize inputs due to synergies between components, specifically fertilizer, putting them at lower risk for nitrogen pollution than other systems [30]. It is well accepted that legume-based systems can reduce nitrogen losses associated with cropping [31] and grazing [32]; therefore, organic producers utilizing mixtures of grass and legume forage species are able to take advantage of naturally occurring nitrogen fixation.

\subsection{Soil Organic Matter}

A number of soil factors can influence forage plant growth and nutrient acquisition, which becomes more critical as the proportion of forages in a ruminant's diet increases. If soil bulk density is excessive, plant root growth will be negatively affected, and if soil becomes dry, the dissolution and movement of nutrient ions in the soil solution will be restricted. The $\mathrm{pH}$ of the soil can also affect the availability of nutrients, some to toxic levels when soils become very acidic, and the proliferation of soil microbes, including those involved with legumes in nitrogen fixation. While high plant productivity can be achieved on unhealthy soils through the additional of high levels of fertilizer, long-term soil health is a goal of organic agricultural systems because these "conventional" options are not available in organic systems [31].

A healthy soil is a soil with an optimal $\mathrm{pH}$, aeration, and nutrient- and water-holding capacity considering the parent material, plant community and climate under which it was formed. A healthy agricultural soil is one that is managed sustainably to improve deficits in any of these traits in support of plant growth without degradation, such as erosion or salinization. One of the most important indicators of a healthy soil is the level of organic matter. Like other carbon-based fuels, organic matter is consumed more rapidly by soil microbes at high temperatures and high levels of oxygen, so while good drainage and aeration are important for root growth, the cultivation required to support annual cropping hastens the breakdown of organic matter. Chemical fertilization stimulates the microbial mineralization of soil organic carbon [33], but the greater agricultural productivity achieved with synthetic nitrogen fertilization can result in higher crop residues and increase soil organic matter. However, high levels of nitrogen and phosphorus fertilization can undermine soil stability and lead to increased erosion [34]. 
Organic matter in the soil is a repository not only of carbon, but of the nitrogen and phosphorus compounds contained in the flora and fauna of which it is comprised. Soil organic matter as humus glues soil particles together, creating structure that is resistant to collapse and therefore is essential to drainage and aeration, soil organic matter has more surface area and a far greater capacity to absorb water than the mineral components of the soil [35], so it not only adsorbs nutrient cations (the soil cation exchange capacity) but can hold nearly its own weight in soil water. Since the quantity of water used by a given plant species is directly proportional to its leaf growth [36], and therefore to its vegetative productivity, the ability of a soil to absorb and release water is a critical trait.

\subsection{The Impact of Grazing Management on Forage Plants}

To the extent that grazed or conserved forages comprise a greater amount of the feed of organic ruminants than non-organically fed ruminant livestock, the health and performance of these animals may be significantly influenced by the mineral composition of forages. The uptake of nutrients by forages is a function of rooting depth, root surface area, and forage plant species. In general, the root length and density of perennial forages is greater than that of annual crops such as soybean, corn or the cereal grains such as wheat or barley [27]. The effective rooting depth of perennial forage legumes may be greater (e.g., alfalfa) or less (e.g., white clover) than that of grasses, and legumes often store carbohydrates and proteins for regrowth underground, in the tap root and crown (the overwintering stem base).

Pasture management can have a profound effect on root function as well as on the botanical composition of pastures: In grasses, the fibrous root systems are comprised of many relatively thin roots, and grasses have a relatively shallow rooting depth. Overgrazing grasses will deplete both the aboveground shoot material as well as the carbohydrate storage of the grass plant, which is located in the stem or leaf bases near the soil surface (stubble), while well-managed grazing of grazing-tolerant forage species can enhance the soil by encouraging the turnover of fibrous roots, increasing soil organic matter. Excessive removal of photosynthetic tissue slows the rate of regrowth of the shoot, which is largely dependent on current photosynthesis to support growth. Overgrazing also results in self-pruning of the root system, because the root has no capacity for photosynthesis and is therefore entirely dependent on current or stored photosynthesis to support the maintenance of existing roots, much less growth. Under continuous grazing, where ruminants have access to a large area of pasture or rangeland for months at a time, the most desirable forage species will be grazed first, and will be re-grazed as soon as they begin regrowth. This undermines the ability of the shoot to compete for sunlight and of the root to compete for water and soil nutrients. Over time, the botanical composition of grazingland will shift away from the most desirable plant species to the least desirable species, which were left ungrazed and able to successfully compete for resources, reproduce vegetatively by tillering, stolons or rhizomes, and complete their life cycle by maturing and distributing seed.

\section{The Effect of Grazing on Ruminants}

Ruminants that acquire the majority of their feed from forages, as hay or by grazing, may be more affected by variations in forage nutrient quality and availability than those on diets that contain higher proportions of supplemental feeds. Further, ruminants may selectively absorb or passively excrete 
mineral nutrients and nitrogen, altering the effect of dietary mineral content. Whitehead [27] notes five homeostatic control mechanisms that help to maintain ruminant nutrient uptake within a healthy range:

(1). Variation in the extent of absorption from the digestive tract.

(2). Variation in the extent of excretion via the feces.

(3). Variation in the extent of excretion via the urine.

(4). Deposition of an excess in the tissues in harmless and/or reserve forms.

(5). Variation in the extent of secretion into milk.

For dairy cows that excrete significant quantities of some mineral nutrients in milk, dietary concentrations may be critical. While there is a metabolically active reserve of calcium and magnesium in bone, the reserve amounts are small relative to intake or excretion. With such a small buffer, a dietary deficiency can rapidly have serious negative or even fatal effects for a cow early in lactation. Therefore the maintenance of a healthy soil with good soil structure to encourage extensive root systems, good water-holding capacity to buffer drought or suboptimal irrigation, and a capacity to provide and retain good soil fertility is fundamental to the sustainability of grazing-based ruminant livestock systems, particularly in pastures regularly used by dairy cows that excrete high levels of mineral nutrients and nitrogen on a daily basis.

\subsection{Forage Plant Nutrition in Pastures}

Plant roots, like soils, have characteristic cation exchange capacities (CEC), influenced by the concentration of carboxylic acids in root cell walls that provide negative charges, especially if the $\mathrm{pH}$ of the soil solution is a unit or two below neutrality ( $\mathrm{pH}$ 5-6) [27]. In general, legume roots have a higher CEC than grasses, and therefore can compete more successfully for divalent cations, such as $\mathrm{Ca}^{2+}$ or $\mathrm{Mg}^{2+}$, in the soil solution; among legumes, white clover accumulates more calcium than other legume species [27]. The balance of cations in the soil can affect their uptake, because much of the uptake of soil nutrients by roots is passive-ions move with water in the soil solution, and move into roots as part of the transpiration stream. Uptake of nutrients that are passively acquired from the soil solution may be higher in mid-summer, when evapotranspiration is high. In contrast, nitrate, phosphate and sulfate are all negatively charged, and therefore are repelled rather than attracted to the negative charges on soil particles and roots.

An excess of potassium $\left(\mathrm{K}^{+}\right)$in the soil solution, which is more likely in heavily manured soils, can result in "luxury uptake" by forages in excess of plant requirements, and lead to an imbalance of high potassium and therefore a relative deficiency of calcium and magnesium [37]. High $\mathrm{K}^{+}$concentrations in forages can result in metabolic issues in grazing ruminants due more to antagonisms with other elements such as calcium $(\mathrm{Ca})$ and magnesium $(\mathrm{Mg})$, than to simple deficiencies. Grass tetany (hypomagnesemia) is characterized by low blood $\mathrm{Mg}$ and usually occurs in beef cows and ewes grazing lush grass pastures during periods of cool and cloudy weather [38-40]. Grass tetany tends to occur when the dietary intake of total $\mathrm{Mg}$ is not particularly low, but instead when factors exist that increase the animal's Mg requirement (early lactation) or reduce the availability of $\mathrm{Mg}$ to the animal. Potassium inhibits the animals' ability to absorb $\mathrm{Mg}$ resulting in a relative deficiency, and therefore the ratio of milliequivalents of $\mathrm{K}$ to $(\mathrm{Ca}+\mathrm{Mg})$ in forage has been used to predict the tetany hazard of 
forages [39]. Furthermore, milk fever (hypocalcemia) is characterized by low levels of blood calcium and most commonly occurs in high producing dairy cows 12 to $24 \mathrm{~h}$ after calving when the sudden demand for $\mathrm{Ca}$ required by the onset of lactation tests the Ca homeostatic capabilities of the animal [41]. Excessive $\mathrm{K}$ concentrations in the prepartum diet of high-producing dairy cows decreases $\mathrm{Ca}$ resorption from the bone resulting in an imbalance in $\mathrm{Ca}$ homeostasis and a possible deficiency regardless of dietary concentrations of $\mathrm{Ca}$ [41]. Soder and Stout [37] noted that the high K concentrations observed in orchardgrass pastures fertilized with a dairy manure slurry could predispose lactating dairy cows to milk fever. Hardeng and Edge [42] examined the incidence of disease between 31 organic and 93 non-organic Norwegian dairy herds and unexpectedly found no differences between the production systems for cases of milk fever. The authors noted that for each $\mathrm{kg}$ increase in peak milk production, the risk of milk fever increased by 5\%; however, the mean maximum milk production for organic herds was $4.6 \mathrm{~kg}$ lower compared to non-organic herds. Therefore, they suggested that the lower milk production found in the organic herds resulted in reduced $\mathrm{Ca}$ depletion from milking compared to non-organic herds [42].

Nitrate toxicity (methaemoglobinaemia) in ruminants grazing forages grown under stressful conditions or on soils that have received high applications of either inorganic (synthetic) or organic (manure) fertilizers and can be an issue in both organic and non-organic grazing systems. Plants take up nitrogen from the soil largely in the form of nitrate $\left(\mathrm{NO}_{3}{ }^{-}\right)$, which under normal growing conditions is rapidly converted to nitrite $\left(\mathrm{NO}_{2}{ }^{-}\right)$, then to ammonia $\left(\mathrm{NH}_{3}\right)$ and finally to plant proteins. However, when plant growth is slowed by stressful environmental conditions (frost, drought, shade), nitrogen in the form of $\mathrm{NO}_{3}{ }^{-}$accumulates in the plant more rapidly than it can be converted to protein. Nitrate itself is not toxic; however, microbial action on $\mathrm{NO}_{3}{ }^{-}$in the rumen results in the conversion of hemoglobin to methemoglobin, which greatly reduces the oxygen carrying capacity of the blood [39]. Nitrate levels remain stable after forage is harvested and cured for hay, but potential for accumulation is variable across forage species, with annual cereals (sorghum-sudan, sudangrass, oats, etc.) and some weeds (pigweed, lambsquarter, smartweed, etc.) documented as nitrate accumulators [38].

Forage micronutrient content is affected by soil content and plant uptake. The availability of the micronutrients iron, zinc, cobalt, manganese and copper is greater in acidic soils, while the availability of molybdenum and selenium is higher in alkaline soils. Iron is primarily used by ruminants to enable hemoglobin to carry oxygen in the blood for respiration; a deficiency can lead to anemia. Manganese, molybdenum, selenium and copper are needed for enzyme activity, and cobalt is a component of vitamin B-12. Zinc is required for enzyme activity, but is also needed to stabilize RNA and DNA, and for membrane function [27]. Deficiencies of manganese are uncommon, but the primary symptom is lameness. Deficiency symptoms of zinc and copper are not specific, but include poor growth in young stock and increased susceptibility to disease. Copper deficiencies are relatively common, and reduced copper absorption can be caused by high dietary molybdenum, sulfur, or zinc. Cobalt deficiencies result in loss of appetite, and are common either where soils are naturally low in cobalt, or where high levels of iron or manganese reduce the availability of cobalt to plants. Excesses of iron or zinc can interact to reduce the absorbance of each other [43]. Selenium is required for the enzyme glutathione peroxidase, and a deficiency of selenium can result in excessive lipid peroxidation, called white muscle disease, which can be fatal in young sheep and cattle. Excessive selenium can also be deadly: most "locoweed" plants are selenium accumulators, and their consumption can produce acute selenium 
toxicity, leading to rapid death; chronic consumption of selenium accumulator plants can lead to blindness or infertility [27].

\subsection{Vitamins and Minerals in Organic Cattle Systems}

Vitamins and minerals are provided to dairy cows in a non-organic system by including them in the total mixed ration (TMR). By mixing vitamins and minerals in a formulated ration, the animals cannot choose to consume more or less of a specific ingredient and selective feeding is limited. The practices of organic dairy producers can include a similar vitamin and mineral supplement using allowed ingredients, but may be more varied in regard to delivering vitamins and minerals. Organic dairy feeding systems range from large scale organic dairies (more common in the western US), where a mixed ration (partial TMR) is used along with required pasture, to small-scale exclusively pasture-based dairies (dominant in the upper Midwest and the northeastern US). When TMRs are not used, vitamin and minerals may be provided for free-choice consumption by animals. Additionally, providing individual minerals (cafeteria style) to allow for a truly free-choice selection instead of mixing or including them in a TMR has been suggested as a way to allow individual animal selection to meet nutritional requirements when forage quality is variable [44]. Beef cattle on pasture and rangeland may be provided free-choice access to mixed vitamin and minerals, a practice that is similar in non-organic and organic beef cow-calf systems. Mixed organic swards containing plants of white clover, chicory and plantain have been found to have greater mineral concentrations compared to perennial ryegrass or timothy [45], as do weeds such as dandelion, dock and chickweed [27]. Soder et al. [46] reported that increasing the biodiversity of a basic orchardgrass-white clover pasture increased mineral concentration of the pasture, particularly when chicory was included in the mixture. Restrictions on herbicide use and the greater biodiversity often found in organic pastures may result in greater concentrations of weeds in organic systems. Therefore, the mixed pastures often found in organic systems may help provide livestock with needed minerals through plant species biodiversity. Similar to the non-organic feed industry, within the organic sector there is a wide range of products marketed to improve animal performance and health. Kelp meal is commonly used as a natural source of chelated minerals throughout the northeastern US on organic dairy farms; however, limited scientific information is available on the impacts of including kelp meal in dairy or beef rations. Allen et al. [47] reported that feeding kelp extract to grazing beef cattle reduced body temperature and increased cell-mediated immune function during hot weather. However, others have reported no benefits to kelp feeding of dairy cattle for long periods of time [48] or short term [49].

\subsection{Treatment of Parasites in Organic Cattle Systems}

Parasitic infections of ruminants as a result of grazing are considered one of the greatest challenges to animal welfare in organic production systems [50]. In non-organic systems, anthelmintics are routinely used to control or prevent heavy infestations of internal parasites. However, this practice is prohibited under the NOP regulations except in extreme cases of heavy infestation [4]. While fluke and lungworm infections can be addressed with some success by vaccinations which are allowed under National Organic Program rules in the US, nematodes continue to pose problems in organic systems. Temperate forages containing condensed tannin (e.g., birdsfoot trefoil, sainfoin, and sulla) have been 
found to have efficacy against nematodes [50,51]. Alternative dewormers such as garlic and diatomaceous earth have shown little efficacy in scientific studies despite anecdotal claims [52,53]. Commonly recommended practices to control internal parasite issues include: (1) graze youngstock on the 'cleanest' pastures (pastures not grazed by animals of the same species within the past year, or pastures that have hay harvested); (2) don't overgraze, which forces animals to graze close to the ground where the highest concentration of parasite larvae reside; (3) utilize rotational grazing; (4) implement multi-species grazing; (5) where possible, break up parasite cycles by making hay at least once annually; and (6) healthy animals improves resistance to parasites, so provide adequate nutrition, clean water, and a balanced trace mineral mix [54,55]. In addition, genetic selection of animals for resistance or resilience to internal parasites may play a more important role in future animal production systems as decreased use of chemicals and increased anthelmintic resistance become more prominent.

\section{Grazing Impacts on the Nutritional Quality of Milk and Meat}

Evidence of improved nutrient content in fruits and vegetables produced under organic conditions is conflicting. Some studies have reported increased nutritional quality in organically raised produce when compared to non-organic produce [56,57], while others have found no differences between production systems $[58,59]$. However, impacts on the nutritional quality of ruminant products from cattle in pasture-based systems compared with non-organic confinement systems have proven to be more quantifiable.

\subsection{Quality Differences of Dairy Products}

Milk and other dairy products are a substantial source of saturated fatty acids (SFA) in the human diet and these fats significantly contribute to the risk of cardiovascular disease [60,61]; however, the value of dairy products as an important source of protein, vitamins, and minerals cannot be ignored. Therefore, improving the fat composition of dairy products by decreasing SFA content and increasing fatty acids that have positive effects on human health would greatly benefit consumers. It is well accepted that fatty acid composition and concentration in milk are dependent on animal physiology (breed, age, stage of lactation) [62,63] and diet [64,65]. Alpha-linolenic acid (ALA) is the primary dietary precursor of omega-3 fatty acids (FA) and conjugated linoleic acid (CLA) in the milk of cattle, and can account for as much as $50-70 \%$ of the total fatty acids found in fresh forage [66,67]. Therefore, it is no surprise that milk from cows grazing fresh grass contains greater concentrations of omega-3 FA and CLA compared to milk from cows consuming conserved forage, corn silage and high-grain rations [64,68-70]. A recent meta-analysis examining 29 previously published studies from 12 countries concluded that organic dairy products contained significantly higher protein, ALA, total omega-3 FAs, CLA and a more desirable omega-3 to omega-6 ratio compared to dairy products derived from non-organic systems [71]. Increasing omega-3 FAs in the human diet is considered beneficial to health and CLAs have been shown to be a powerful anticarcinogen in animal models [72].

In 2011, milk sold as certified organic in the United States reached nearly 1.2 billion $\mathrm{kg}$ and was valued at 7.6 million US dollars [2], representing an ever growing segment of the dairy industry. The implementation of the pasture rule insures that $30 \%$ of dry matter feed intake by certified organic 
ruminants will be obtained by grazing certified organic pasture or rangeland during at least 120 days of the year. Improvements in the fatty acid profile of organic dairy products, including greater omega-3 FA and CLA concentrations and more desirable omega-3 to omega-6 FA ratios will result from the organic grazing requirement. This is evident in England, where organic dairy production standards require a reliance on forage, and greater concentrations of omega-3 FA, CLA, and fat-soluble antioxidants have been found in organic milk compared to milk from drylot systems $[73,74]$. Seasonal variation in the fatty acid profile of milk produced under grazing conditions is a challenge associated with producing and marketing products that may be considered "enriched" with beneficial fatty acids. Concentrations of nutritionally beneficial fatty acids have been found to be greater in raw and retail milk during the grazing season compared to periods when the animals were consuming a greater proportion of grain and conserved forages [74,75]. Supplementing the diets of milking cows with oilseeds such as flax may be a method of elevating desirable milk fats when fresh forage is limited by seasonality or drought [69].

\subsection{Quality Differences of Beef Products}

The impacts of forage feeding on production and quality of the end-products of beef cattle are varied. It is generally accepted that steers finished in a forage-based system have leaner, lighter carcasses (or must spend more time on feed to reach equivalent carcass weights) and may produce beef with a greater intensity of off-flavor, compared to those from grain-based systems [76-79]. Some direct comparisons of grain- and grass-finished beef have reported undesirable eating characteristics (specifically tenderness and juiciness) of forage finished beef, but these studies were confounded by age at slaughter or plane of nutrition effects [80-82]. Duckett et al. [77] compared forage (alfalfa, pearl millet or mixed pasture) and grain-based (corn-silage) finishing diets on carcass and meat quality of Angus-cross steers when finished to an equal time point. As expected, the authors found forage-finished steers to have $46 \%$ less total fat on the 9 th to 11 th rib section. No differences in meat quality and eating quality parameters, including juiciness and overall tenderness, were reported between the finishing systems; however, a trained sensory panel found a tendency for the forage-finished beef to have a greater intensity of off-flavor [77].

Increasing the vitamin E content of beef, specifically through grass feeding, has been suggested as a potential method to stabilize some of the negative sensory and storage effects associated with altered fatty acid content of forage finished beef [83]. Further research has focused on the impacts of forage finishing on altering fatty acid composition of beef products, specifically reducing SFA content, improving the omega- 6 to omega-3 FA ratio, enhancing CLA content and increasing B-vitamins and antioxidants. Beef from cattle produced in forage-based systems have a lower overall fat content and greater omega-3 FA and CLA content compared to beef from cattle finished using grain-based diets [77,83-85]. Moreover, vitamin E and $\beta$-carotene concentrations have been found to be greater in beef finished on pasture compared to traditional finishing programs [84]. However, it is important to note that while the concentrations of beneficial fatty acids are greater in forage-finished beef, the total fat content is lower, and therefore may impact the total amount (as $\mathrm{mg} / \mathrm{d}$ ) of beneficial fatty acids in whole cuts of beef. Additionally, while forage feeding increases some beneficial fatty acids that have been prominent topics in current human health trends (e.g., omega-3 FA and CLA), the impact on other fats and their potential for human health benefits have received less attention. Concentrate-finishing 
enhances oleic acid concentration in beef [77,86], and diets high in mono-unsaturated fatty acids (MUFA), specifically oleic acid, can lower the concentrations of undesirable low-density-lipoprotein cholesterol (LDL) humans [87]; low-density-lipoprotein cholesterol represents a significant risk factor for cardiovascular disease and are considered the "bad cholesterol" [88]. More research is needed on the direct human health effects of consuming beef products considered enriched with omega-3 FA and CLAs (forage fed) or with oleic acid (concentrate-finished).

Consumers are willing to pay a premium for animal products from organic systems because they should not contain residues of the synthetic chemicals (pesticides, herbicides, fertilizers, fungicides and veterinary drugs) that are used in non-organic ruminant production systems [89]. However, the nutritional benefits from organic milk and meat products in the form of healthier fat composition and increased antioxidant and vitamin properties are due to dietary factors that are used in but not exclusive to organic systems, specifically greater pasture consumption of organic dairy and beef cattle compared to those in non-organic systems. However, grazing-based dairy and beef systems (including certified organic systems) do not have exclusive claims to these greater levels of potentially beneficial components in meat and milk products. It is possible to increase beneficial fatty acids and other nutritional components of meat and milk in confinement feeding through the use of supplemental feeds such as oilseeds [90,91] or fish oil [92].

\section{Greenhouse Gas Implications of Organic and Non-Organic Production}

\subsection{Greenhouse Gas Emissions in Dairy Systems}

Greenhouse gas (GHG) emissions from organic dairy systems have been found to be lower on a per-ha area than emissions from non-organic dairy systems across a range of environments in western Europe, based on whole-farm assessments using the FarmGHG model [93]. Life cycle assessments (LCA) that compared organic and non-organic dairy systems in Scandinavia [29] and in the Netherlands [94] also identified advantages in organic dairy production. Lynch et al. [95] noted the scarcity of US and Canadian data for GHG emissions associated with dairy systems. A US comparison of organic, non-organic, and non-organic plus recombinant bovine somatotropin (rbST) dairy production, which included the GHG value of measured inputs, outputs and land area, concluded that organic systems had the highest environmental impact [96]. However, this study focused on the efficiency of production per cow and was neither a whole-farm study nor a LCA; therefore, the implications of related factors, such as culling rate, were not considered. Even the LCA and whole-farm modeling studies did not include the economic or social values of these systems or their ecosystem services.

According to a Food and Agriculture Organization LCA of the dairy sector, US milk production represents about $16 \%$ of the world total, while the relative contribution of the GHG emissions, per $\mathrm{kg}$ of fat- and protein-corrected milk (FPCM), associated with milk production, processing and transportation in the US, is about $8 \%$ of the world total. This ratio of GHG emissions to milk production is the lowest of any global region, including western Europe [97] (Figure 4.2). Within this highly efficient US dairy sector, organic accounts for only about $4 \%$ of production [98], but organic dairy sales have continued to increase by double digits, even during the Great Recession that began in 2008 [99]. 


\subsection{Greenhouse Gas Emissions in Beef Systems}

While the per-head carbon footprint of grain-finished cattle was higher as estimated by Peters et al. [100] in an Australian study, it was offset by high feedlot rates of gain. However, the contribution of legumes in pastures was not determined in that study, and in a review of greenhouse gas emissions from beef and dairy cattle production systems, no reference was made to forage legumes [101]. There is an opportunity to reassess these beef LCA incorporating MiG and high-quality forages that can greatly increase the rate of gain of cattle finished on pasture. Evidence for this comes from studies of plants used for biofuel production. Kim and Dale [102] reported that alfalfa, a perennial, N-fixing legume, resulted in the lowest $\mathrm{g}$ carbon-equivalent per-kg biomass emissions among corn (246-286), soybeans (159-163) and switchgrass (124-147) compared with just 89 for alfalfa. Finishing beef cattle on high quality pastures can reduce GHG emissions and the global warming potential (GWP) associated with grass finished beef. This can occur through increased sequestration of $\mathrm{CO}_{2}$ into soil organic carbon and/or through decreased emissions of $\mathrm{N}_{2} \mathrm{O}$ and methane with their potent GWP [103,104]. Rangelands and pastures are well-known for their ability to increase soil carbon stocks [105], and this trait should differ little between non-organic and organic systems.

Beef cattle production conducted on rangeland generally requires a significant amount of land, and therefore tends to be extensive and uncultivated with intact natural biodiversity [106]. There are approximately 2 million acres of certified organic rangeland in the US [107], but little information is available on the implications of management practices specific to certified organic rangeland, much of which is found in the western US. Because chemical fertilization and weed control are usually not economically feasible on non-organic rangeland, organic rangeland would not be expected to differ greatly from non-organic. In a review by Sayre et al. [106], it was noted that ranching conducted on rangelands exemplifies many of the defining characteristics of diversified farming systems, as it relies on the functional diversity of natural processes of both plants and animals and creates services generated and regenerated locally without nonrenewable inputs.

\section{Economics of Grazing-Based Cattle Systems}

Feed is the greatest cost associated with milk and meat production [108]. Therefore, when grazed forage can replace the use of more expensive grains or conserved forages it is possible to decrease the input costs of ruminant production systems.

\subsection{Economics of Dairy Systems}

Many studies have conducted direct comparisons of pasture-based (but not necessarily organic) and confinement dairy systems and have reported that producers utilizing grazing have lower milk production per cow but also have lower operating expenses and greater net incomes per cow compared with confinement systems [108-112]. In a 4-year study, White et al. [108] examined economic measures in pasture systems using Holstein and Jersey cows and found that cows in a pasture-based system produced $11 \%$ less milk than cows in confinement. However, feed costs were on average $31 \%$ lower for the grazing cows compared to cows in confinement, and income over feed was found to be the same between the two systems. Within organic systems, McBride and Greene [113] noted that 
while feed costs per cow were $25 \%$ less for organic dairies that used pasture for the majority of their feed compared with organic dairies that used the least pasture, milk production on pasture-intensive organic dairies was $30 \%$ less than for dairies with minimal pasture use. However, this study was conducted before the implementation of the pasture rule in 2010 which will have significantly increased the pasture feeding of organic cows previously fed like non-organic dairy cows but with organically sourced feeds.

In general, economic factors including labor for animal care, manure handling, forage management and cow culling rates were more desirable for pasture-based systems. Veterinary costs were lower for organic than non-organic dairy farms in the Netherlands [114] and the health of organic dairy cows was found to be better than that of non-organic dairy cows [115]. Organic dairy cows spend more time grazing, which results fewer hoof and leg problems in part due to spending less time on concrete, and organic dairy producers are more inclined to administer approved remedies or take a wait-and-see approach before contacting a veterinarian [42]. Hanson et al. [111] examined farm income tax returns from 62 dairy farms in the mid-Atlantic region to evaluate financial performance of dairy producers utilizing either MiG or confinement production systems. The authors found that purchased feed expenses were $31 \%$ less in the MiG systems compared to confinement systems (267 vs. 387 \$acre, respectively). Additionally, MiG operations produced less milk but had substantially lower costs of production and were more profitable than confinement operations per hundredweight of milk produced and on a per-cow basis. Moreover, there was no impact on total farm profitability between the production systems.

Grazing-based dairy systems are the dominant dairy production model in New Zealand, Australia and the European Union [116,117]; however, not all grazing-based dairies are organic. On a world scale, Dillon et al. [118] found a strong inverse relationship between costs of production and proportion of grazed forage in the cow's diet, and reported that Australia and New Zealand had the greatest proportion of the diet provided by grass $(85 \%-90 \%)$ and the lowest cost of production of all the countries evaluated. Additionally, the authors noted that increasing the proportion of grazed grass in a system where pasture was already the predominant feed will reduce the cost of production. For example, extending the grazing season by 27 days in Irish systems reduced the cost of milk by 1 cent/L [118]. In Europe, pasture is generally accepted as the cheapest feed source for dairy cattle and forms the base for profitable low-input systems in this region [119].

Reliable studies directly comparing the economics of organic and non-organic milk production in the US are limited, and those studies conducted previous to the 2010 pasture rule may not apply to the economics of organic systems today. Butler [120] compared production costs of organic and non-organic dairy farms in California and found the total cost of milk production per cwt (45 kg) was 16\% higher in the organic system due largely to greater feed, labor, herd replacement and transition costs. However, the authors acknowledged that feed costs, which make up half of total production costs, were not as high as expected in the organic systems due to the utilization of low-cost pasture. A study by Rotz et al. [121] demonstrated that organic dairies typical of the northeastern US were more profitable than comparably sized non-organic dairies, but that profitability depended on a premium price for organic milk. 


\subsection{Economics of Beef Systems}

The impact of grazing on profitably of the beef industry as a whole is complicated given the segmentation of a typical animal's life into a cow-calf suckling/grazing period, a growing/developing period for replacement stock or a growing/fattening period for slaughter stock. More than $70 \%$ of the lifetime body weight of a beef animal destined for slaughter is spent on forages and up to $100 \%$ of the life of beef breeding stock may be spent on pastures or conserved forages [122]; however, the degree of grain supplementation varies by region. The cow-calf sector represents a part of the industry where animals spend a significant amount of time on pasture and rangeland and generally require a minimal amount of purchased feed prior to finishing. Therefore, this phase may already be similar to practices of organic systems [123] and adjustments to adhere to organic standards would be more focused on eliminating the use of implantable growth promotants and antibiotics rather than feeding and housing.

When evaluating costs of production during the growing and finishing phase, Fernandez and Woodward [124] found that the cost of gain was greater for calves in an organic system compared to calves fed in a non-organic system (\$1.89 vs. $\$ 1.36 / \mathrm{kg}$ gain, respectively). In non-organic beef finishing systems the major determinant for cost of gain is the price of feed, and in this study $79 \%$ of the cost of gain was due to feed costs for the organically raised steers, where $73 \%$ of the cost of gain was due to feed for the non-organically raised steers, with these costs heavily dependent on the price of organic and non-organic corn. This study was conducted before the implementation of the pasture rule and did not address profit, which would include premiums for the sale of organically raised cattle. However based on cost of gain, the organic steers cost $39 \%$ more to finish than the non-organically raised steers, when grain-finishing was used [124].

Increasing corn and soybean prices due to expanding demand of these commodities for agrofuel production have impacted both non-organic and organic ruminant production systems that depend on high-grain feeds to maximize production. The price of organic feed corn increased from an average of $\$ 5.22 /$ bu in 2010 to $\$ 10.68 /$ bu in 2011 [98] causing many livestock producers to explore alternative feed sources in an effort to become less dependent on cereal grains. Moreover, increased input costs from energy-dense feeds like cereal grains caused some producers to evaluate the economics of pasturing calves in stocker systems or forage finishing beef in an effort to reduce cost of gain. Lewis et al. [125] evaluated the economics of an intensive beef production system, where cattle were weaned and immediately finished on a high-grain diet compared with an extensive system where calves were weaned, wintered on crop residues, grazed on summer pastures and then finished on a high-grain diet. The break-even price for cattle in the extensive system was significantly lower due to the additional body weight added to the animals from grazing forage before entering the feedlot. Cattle in the extensive system produced more total beef at a lower cost per unit of product. The profitability of the extensive system was due largely to the low cost of forage feeding.

Currently, few reliable direct comparisons have been made regarding profitability between organic and non-organic ruminant production systems in the United States; however, increased utilization of grazed forages is generally associated with reduced feed costs and lower costs of production per animal in both dairy and beef systems. Therefore, the use of grazing to meet the requirements of the NOP pasture rule may subsequently reduce input costs and contribute to economic profitability in organic ruminant production systems more than premiums from the organic label itself. 


\section{Social Implications of Organic vs. Non-organic Cattle Production Systems}

Organic agriculture is founded on a set of principles that guide the technical approach to plant and animal production, but which also accept responsibility for the environmental and social consequences of food production. The four principles of organic agriculture, as articulated by the International Federation of Organic Agriculture Movements, are as follows:

The Principle of Health - Organic agriculture should sustain and enhance the health of soil, plant, animal, human and planet as one and indivisible.

The Principle of Ecology-Organic agriculture should be based on living ecological systems and cycles, work with them, emulate them and help sustain them.

The Principle of Fairness - Organic agriculture should build on relationships that ensure fairness with regard to the common environment and life opportunities.

The Principle of Care-Organic agriculture should be managed in a precautionary and responsible manner to protect the health and well being of current and future generations and the environment.

The social implications of beef and dairy production practices are more difficult to quantify than production or economics, but the welfare of farm workers is predicted to be the "next chapter of the food movement" by Michael Pollan [126]. The effects of organic livestock production on rural communities, land stewardship and human health have already been considered:

Rural Communities: Organic agriculture strives to be sustainable and therefore to protect the whole of the environment [127], including workers, owners, and the rural communities to which they belong. The greater use of pasture in organic dairy and beef production systems due to the pasture rule has the potential to influence farm size, which may be more important than farm type in predicting community participation and involvement. The premium that consumers are willing to pay for organically produced food allows small, labor-intensive businesses to prosper. Additionally, the use of locally available inputs is encouraged in organic agriculture, which in turn increases demand for other local businesses. Sustaining smaller organic dairies and beef producers by enforcing the pasture rule and supporting a premium price for organic beef should result in more farm residents, which should benefit communities [128]. However, the total number of organic producers within dairy or ranching communities is small, making the impact of this factor difficult to quantify.

Land Stewardship: Protecting and enhancing soil fertility by adding manure, compost or by growing and plowing under cover crops is important in organic agriculture, not only to improve the current land productivity, but also to ensure production for future generations. Where perennial pastures replace cropping systems, there will be a decrease in soil erosion, cultivation and harvesting, and an increase in organic matter and (where nitrogen-fixing legumes are used) an increase in the nitrogen content of the soil, supporting productivity and the cycling of mineral nutrients through forage use and the return of nutrients to the soil as urine and dung.

Human Health: Organic dairy and beef products are not contaminated with pesticide, hormone or antibiotic residues, and have been shown to have improved nutritional content, including increased beneficial nutrients such as omega-3 fatty acids and conjugated linoleic acids [129]. A strongly 
positive public perception of the perceived benefits results in increased consumption of organic foods by consumers.

There is increasing interest in organic and sustainable cattle production systems by both producers and consumers, which can be seen in the continued willingness of consumers to pay more for organic products and in the continued expansion of the organic beef and dairy agricultural sectors to meet this need. However, organic production still constitutes too small a segment of dairy and beef production for the potential impacts on rural communities, farm families, and farm workers to be quantified.

\section{Conclusions}

One of the most significant differences between organic and non-organic US dairy and beef production systems is the greater use of pasture in US organic systems. There are also non-organic grazing-based dairies as well as grass-finished beef enterprises that have more in common with US organic dairy and beef systems than with large-scale commercial non-organic operations. Among the implications of feeding cattle on pasture for a significant portion of the year are differences in manure management and soil organic matter, and greater vulnerability of cattle to certain nutrient deficiencies and parasites. It is more challenging to provide some mineral nutrients for organic crop production, so organic beef and dairy systems require longer-term nutrient planning and are more likely than non-organic systems to develop deficiencies in phosphorus, potassium and sulfur. However, because nitrogen is supplied from livestock manure or green manure in organic systems, soil organic matter tends to be higher in organic than non-organic systems. The economic well-being of US organic beef and dairy systems depends on the willingness of consumers to pay a premium for organically produced livestock products, and the increasing cost of nitrogen fertilizer and cereal grains as livestock feed creates a further incentive for beef and dairy producers to increase the use of pasture. The differences in the fatty acid composition of organic milk and meat are well-documented, and consumer preference for purchasing livestock products that have been produced without the use of antibiotics or growth hormones continues to increase; therefore, certified organic agriculture continues to be the fastest growing sector of US agriculture.

\section{References and Notes}

1. Marston, S.P.; Clark, G.W.; Anderson, G.W.; Kersbergen, R.J.; Lunak, M.; Marcinkowski, D.P.; Murphy, M.R.; Schwab, C.G.; Erickson, P.S. Maximizing profit on New England organic dairy farms: An economic comparison of 4 total mixed rations for organic Holsteins and Jerseys. J. Dairy Sci. 2011, 94, 3184-3201.

2. United States Department of Agricultue, National Agricultural Statistics Service (USDA-NASS). 2011 Certified Organic Production Survey; United States Department of Agriculture-National Agricultural Statistics Service: Washington, DC, USA, 2012.

3. Mirzaei-Aghsaghali, A.; Maheri-Sis, N. Nutritive value of some agro-industrial by-products for ruminants-A review. World J. Zool. 2008, 3, 40-46.

4. Rinehart, L.; Baier, A. Pasture for Organic Ruminant Livestock: Understanding and Implementing the National Organic Program (NOP) Pasture Rule; United States Department of 
Agriculture, National Center for Appropriate Technology, National Sustainable Agriculture Information Service (ATTRA): Washington, DC, USA, 2011.

5. Sato, K.; Bartlett, P.C.; Erskine, R.J.; Kaneene, J.B. A comparison of production and management between Wisconsin organic and conventional dairy herds. Livest. Prod. Sci. 2005, 93, 105-115.

6. Gillespie, J.; Nehring, R.; Hallahan, C.; Sandretto, C. Pasture-based dairy systems: Who are the producers and are their operations more profitable than conventional dairies? J. Agr. Resour. Econ. 2009, 34, 412-427.

7. Hoshide, A.K.; Halloran, J.M.; Kersbergen, R.J.; Griffin, T.S.; DeFauw, S.L.; LaGasse, B.J.; Jain, S. Effects of stored feed cropping systems and farm size on the profitability of Maine organic dairy farm simulations. J. Dairy Sci. 2011, 94, 5710-5723.

8. Zwald, A.G.; Ruegg, P.L.; Kaneene, J.B.; Warnick, L.D.; Wells, S.J.; Fossler, C.; Halbert, L.W. Management practices and reported antimicrobial usage on conventional and organic dairy farms. J. Dairy Sci. 2004, 87, 191-201.

9. Benbrook, C. Shades of Green: Quantifying the Benefits of Organic Dairy Production; The Organic Center: Washington, DC, USA, 2009.

10. Matthews, K.H.; Johnson, R.J. Alternative Beef Production Systems: Issues and Implications. United States Department of Agriculture, Economic Research Service. LDPM-218-01: 2013. Available online: http://www.ers.usda.gov/media/1071057/ldpm-218-01.pdf (accessed on 2 July 2013).

11. Cornucopia Institute. Position Paper on Organic Beef Finishing and Proposal for Three Tiered Labeling System for Organic Meat from Ruminants; Cornucopia Institute: Cornucopia, WI, USA, 2010.

12. Coffey, L.; Baier, A.H. Guide for Organic Livestock Producers; United States Department of Agriculture, National Center for Appropriate Technology, National Sustainable Agriculture Information Service (ATTRA): Butte, MT, UDA, 2012.

13. Kolok, A.S.; Sellin, M.K. The Environmental Impact of Growth-Promoting Compounds Employed by the United States Beef Cattle Industry: History, Current Knowledge, and Future Directions. In Reviews of Environmental Contamination and Toxicology; Whitacre, D.M., Ed.; Springer: New York, NY, USA, 2008; pp. 1-30.

14. Rogers, S.; Haines, J. Detecting and Mitigating the Environmental Impact of Fecal Pathogens Originating from Confined Animal Feeding Operations: Review; EPA/600/R-06/021: 2005; United States Envrionmental Protection Agency, National Risk Management Research Laboratory, Office of Research and Development: Cincinnati, OH, USA, 2005.

15. Allen, V.G.; Batello, C.; Berretta, E.J.; Hodgson, J.; Kothmann, M.; Li, X.; McIvor, J.; Milne, J.; Morris, C.; Peeters, A.; et al. An international terminology for grazing lands and grazing animals. Grass Forage Sci. 2011, 66, 2-28.

16. Walton, P.D.; Martinez, R.; Bailey, A.W. A comparison of continuous and rotational grazing. J. Range Manage. 1981, 34, 19-21.

17. Condron, L.M.; Cameron, K.C.; Di, H.J.; Clough, T.J.; Forbes, E.A.; McLaren, R.G.; Silva, R.G. A comparison of soil and environmental quality under organic and conventional farming systems in New Zealand. New Zeal. J. Agr. Res. 2000, 43, 443-466.

18. Reganold, J.P.; Palmer, A.S.; Lockhart, J.C.; Macgregor, A.N. Soil quality and financial performance of biodynamic and conventional farms in New Zealand. Science 1993, 260, 344-349. 
19. Liebig, M.A.; Doran, J.W. Impact of organic production practices on soil quality indicators. J. Environ. Qual. 1999, 28, 1601-1609.

20. Nguyen, M.L.; Haynes, R.J.; Goh, K.M. Nutrient budgets and status in three pairs of conventional and alternative mixed cropping farms in Canterbury, New Zealand. Agr. Ecosyst. Environ. 1995, $52,149-162$.

21. Løes, A.-K.; Øgaard, A.F. Long-term changes in extractable soil phosphorus (P) in organic dairy farming systems. Plant Soil 2001, 237, 321-332.

22. Cornforth, I.S.; Sinclair, A.G. Model for calculating maintenance phosphate requirements for grazed pastures. New Zeal. J. Exp. Agr. 1982, 10, 53-61.

23. Gosling, P.; Shepherd, M. Long-term changes in soil fertility in organic arable farming systems in England, with particular reference to phosphorus and potassium. Agr. Ecosyst. Environ. 2005, $105,425-432$.

24. Soder, K.J.; Holden, L.A. Use of anionic salts with grazing prepartum dairy cows. Prof. Anim. Scientist 1999, 15, 278-285.

25. Bulluck, L.R.; Brosius, M.; Evanylo, G.K.; Ristaino, J.B. Organic and synthetic fertility amendments influence soil microbial, physical and chemical properties on organic and conventional farms. Appl. Soil Ecol. 2002, 19, 147-160.

26. National Academy of Sciences. In Watershed Management for Potable Water Supply: Assessing the New York City Strategy; National Academy Press: Washington, DC, USA, 2000.

27. Whitehead, D.C. In Nutrient Elements in Grassland: Soil-Plant-Animal Relationships; CABI: Wallingford, Oxon, UK, 2000.

28. Peterson, P.R.; Gerrish, J.R. Grazing management affects manure distribution by beef cattle. Available online: http://aes.missouri.edu/fsrc/research/afgc95pp.stm (accessed on 19 May 2013).

29. Cederberg, C.; Mattsson, B. Life cycle assessment of milk production-a comparison of conventional and organic farming. J. Clean. Prod. 2000, 8, 49-60.

30. Ryschawy, J.; Choisis, N.; Choisis, J.P.; Joannon, A.; Gibon, A. Mixed crop-livestock systems: An economic and environmental-friendly way of farming? Animal 2012, 6, 1722-1730.

31. Drinkwater, L.E.; Wagoner, P.; Sarrantonio, M. Legume-based cropping systems have reduced carbon and nitrogen losses. Nature 1998, 396, 262-265.

32. Peoples, M.B.; Baldock, J.A. Nitrogen dynamics of pastures: Nitrogen fixation inputs, the impact of legumes on soil nitrogen, fertility, and the contributions of fixed nitrogen to Australian farming systems. Aust. J. Exp. Agr. 2001, 41, 324-346.

33. Khan, S.A.; Mulvaney, R.L.; Ellsworth, T.R.; Boast, C.W. The myth of nitrogen fertilization for soil carbon sequestration. J. Environ. Qual. 2007, 36, 1821-1832.

34. Blanco-Canqui, H.; Schlegel, A.J. Implications of inorganic fertilization of irrigated corn on soil properties: Lessons learned after 50 years. J. Environ. Qual. 2013, 42, 861-871.

35. Brady, N. The Nature and Property of Soils, 10th ed.; Pearson: Upper Saddle River, NJ, USA, 1990.

36. James, D.W.; Hanks, R.J.; Jurinak, J.J. Modern Irrigated Soils; Wiley: New York, NY, USA, 1982.

37. Soder, K.J.; Stout, W.L. Effect of soil type and fertilization level on mineral concentration of pasture: Potential relationships to ruminant performance and health. J. Anim. Sci. 2003, 81, $1603-1610$. 
38. Ball, D.M.; Hoveland, C.S.; Lacefield, G.D. Southern Forages: Modern Concepts for Forage Crop Management, 4th ed.; Graphic Communications Corporation: Lawrenceville, GA, USA, 2007.

39. Church, D.C. The Ruminant Animal: Digestive Physiology and Nutrition; Waveland Press, Inc.: Prospect Heights, IL, USA, 1988.

40. Van Soest, P.J. Nutritional Ecology of the Ruminant, 2nd ed.; Cornell University Press: Ithaca, New York, NY, USA, 1994.

41. Goff, J.P.; Horst, R.L. Effects of the addition of potassium or sodium, but not calcium, to prepartum rations on milk fever in dairy cows. J. Dairy Sci. 1997, 80, 176-186.

42. Hardeng, F.; Edge, V.L. Mastitis, ketosis, and milk fever in 31 organic and 93 conventional Norwegian dairy herds. J. Dairy Sci. 2001, 84, 2673-2679.

43. Zollitsch, W.; Kristensen, T.; Krutzinna, C.; MacNaeihde, F.; Younie, D. Feeding for Health and Welfare: The Challenge of Formulating Well-balanced Rations in Organic Livestock Production. In Animal Health and Welfare in Organic Agriculture; Vaarst, M., Roderick, S., Lund, V., Lockeretz, W., Eds.; CABI Publishing: Wallingford, Oxon, UK, 2004; pp. 329-356.

44. Beal, S. Free Choice Smorgasbord Vitamin and Mineral Supplementation for Livestock. NODPA News, 2010, 10, 8-9, 30-31.

45. Weller, R.F.; Bowling, P.J. The yield and quality of plant species grown in mixed organic swards. In Organic Meat and Milk from Ruminants; Kyriazakis, I., Zervas, G., Eds.; Wageningen Academic Publishers: Wageningen, The Netherlands, 2002; pp. 177-183.

46. Soder, K.J.; Sanderson, M.A.; Stack, J.L.; Muller, L.D. Intake and performance of lactating cows grazing diverse forage mixtures. J. Dairy Sci. 2006, 89, 2158-2167.

47. Allen, V.G.; Pond, K.R.; Saker, K.E.; Fontenot, J.P.; Bagley, C.P.; Ivy, R.L.; Evans, R.R.; Schmidt, R.E.; Fike, J.H.; Zhang, X.; et al. Tasco: Influence of a brown seaweed on antioxidants in forages and livestock-A review. J. Anim. Sci. 2001, 79, E21-E31.

48. Berry, M.H.; Turk, K.L. The value of kelp meal in rations for dairy cattle. J. Dairy Sci. 1944, 27, 861-866.

49. Soule, G.M.; Brito, A.F.; Miranda, A.; Chase, L.; Whitehouse, N.L.; Fletcher, E.S.; Antaya, N.T. Effects of kelp meal on performance and structural growth of conventional and organic dairy calves. J. Dairy Sci. 2012, 95(Suppl. 2), 109.

50. Younie, D.; Thamsborg, S.M.; Ambrosini, F.; Roderick, S. Grassland Management and Parasite Control. In Animal Health and Welfare in Organic Agriculture; Vaarst, M., Roderick, S., Lund, V., Lockeretz, W., Eds.; CABI Publishing: Wallingford, Oxon, UK, 2004; pp. 308-328.

51. Hoste, H.; Jackson, F.; Athanasiadou, S.; Thamsborg, S.M.; Hoskin, S.O. The effects of tannin-rich plants on parasitic nematodes in ruminants. Trends Parasitol. 2006, 22, 253-261.

52. Bernard, G.; Worku, M.; Ahmedna, M. The effects of diatomaceous earth on parasite-infected goats. Bull. Georgian Natl. Acad. Sci. 2009, 3, 129-135.

53. Burke, J.M.; Wells, A.; Casey, P.; Miller, J.E. Garlic and papaya lack control over gastrointestinal nematodes in goats and lambs. Vet. Parasitol. 2009, 159, 171-174.

54. Kunkel, J.R.; Murphy, W.M.; Rogers, D.; Dugdale, D.T. Seasonal control of gastrointestinal parasites among dairy heifers. Bovine Pr. 1983, 18, 54-57.

55. Myers, G.H. Strategies to control internal parasites in cattle and swine. J. Anim. Sci. 1988, 66, $1555-1564$. 
56. Worthington, V. Nutritional quality of organic versus conventional fruits, vegetables, and grains. J. Altern. Complem. Med. 2001, 7, 161-173.

57. Heaton, S. Assessing organic food quality: Is it better for you? In UK Organic Research 2002, Proceedings of the COR Conference, 26-28 March 2002; Powell, J., Ed.; University of Wales: Aberystwyth, UK, 2002; pp. 55-60.

58. Bourn, D.; Prescott, J. A comparison of the nutritional value, sensory qualities, and food safety of organically and conventionally produced foods. CRC Cr. Rev. Food Sci. 2002, 42, 1-34.

59. Magkos, F.; Arvaniti, F.; Zampelas, A. Organic food: Nutritious food or food for thought? A review of the evidence. Int. J. Food Sci. Nutr. 2003, 54, 357-371.

60. Givens, D.I. Milk and meat in our diet: Good or bad for health? Animal 2010, 4, 1941-1952.

61. Shingfield, K.J.; Bonnet, M.; Scollan, N.D. Recent developments in altering the fatty acid composition of ruminant-derived foods. Animal 2013, 7, 132-162.

62. Lock, A.L.; Garnsworthy, P.C. Seasonal variation in milk conjugated linoleic acid and delta9desaturase activity in dairy cows. Livest. Prod. Sci. 2003, 79, 47-59.

63. Palmquist, D.L.; Beaulieu, D.; Barbano, D.M. Feed and animal factors influencing milk fat and composition. J. Dairy Sci. 1993, 76, 1753-1771.

64. Chilliard, Y.; Ferlay, A. Dietary lipids and forages interactions on cow and goat milk fatty acid composition and sensory properties. Reprod. Nutr. Dev. 2004, 44, 467-492.

65. Chilliard, Y.; Glasser, F.; Ferlay, A.; Bernard, L.; Rouel, J.; Doreau, M. Diet, rumen biohydrogenation and nutritional quality of cow and goat milk fat. Eur. J. Lipid Sci. Tech. 2007, 109, 828-855.

66. Elgersma, A.; Tamminga, S.; Dijkstra, J. Lipids in herbage. In Fresh Herbage for Dairy Cattle; Elgersma, A., Dijikstra, J., Tamminga, S., Eds.; Springer: Wageningen, The Netherlands, 2006; pp. 175-194.

67. Ferlay, A.; Agabriel, C.; Sibra, C.; Journal, C.; Martin, B.; Chilliard, Y. Tanker milk variability in fatty acids according to farm feeding and husbandry practices in a French semi-mountain area. Dairy Sci. Technol. 2008, 88, 193-215.

68. Chilliard, Y.; Ferlay, A.; Doreau, M. Effect of different types of forages, animal fat or marine oils in cow's diet on milk fat secretion and composition, especially conjugated linoleic acid (CLA) and polyunsaturated fatty acids. Livest. Prod. Sci. 2001, 70, 31-48.

69. Dewhurst, R.J.; Shingfield, K.J.; Lee, M.R.F.; Scollan, N.D. Increasing the concentrations of beneficial polyunsaturated fatty acids in milk produced by dairy cows in high-forage systems. Anim. Feed Sci. Tech. 2006, 131, 168-206.

70. Elgersma, A.; Tamminga, S.; Ellen, G. Modifying milk composition through forage. Anim. Feed Sci. Tech. 2006, 131, 207-225.

71. Palupi, E.; Jayanegara, A.; Ploeger, A.; Kahl, J. Comparison of nutritional quality between conventional and organic dairy products: A meta-analysis. J. Sci. Food Agric. 2012, 92, 2774-2781.

72. Ip, C.; Banni, S.; Angioni, E.; Carta, G.; McGinley, J.; Thompson, H.J.; Barbano, D.; Bauman, D. Conjugated linoleic acid-enriched butter fat alters mammary gland morphogenesis and reduces cancer risk in rats. J. Nutr. 1999, 129, 2135-2142. 
73. Butler, G.; Nielsen, J.H.; Slots, T.; Seal, C.; Eyre, M.D.; Sanderson, R.; Leifert, C. Fatty acid and fat-soluble antioxidant concentrations in milk from high- and low-input conventional and organic systems: Seasonal variation. J. Sci. Food Agric. 2008, 88, 1431-1441.

74. Butler, G.; Stergiadis, S.; Seal, C.; Eyre, M.; Leifert, C. Fat composition of organic and conventional retail milk in northeast England. J. Dairy Sci. 2011, 94, 24-36.

75. Wyss, U.; Miinger, A.; Collomb, M. Variation of fatty acid content in grass and milk during the grazing season. Grassland Sci. Eur. 2010, 15, 422-424.

76. Duckett, S.K.; Neel, J.P.; Sonon, R.N.; Fontenot, J.P.; Clapham, W.M.; Scaglia, G. Effects of winter stocker growth rate and finishing system on: II. Ninth-tenth-eleventh-rib composition, muscle color, and palatability. J. Anim. Sci. 2007, 85, 2691-2698.

77. Duckett, S.K.; Neel, J.P.S.; Lewis, R.M.; Fontenot, J.P.; Clapham, W.M. Effects of forage species or concentrate finishing on animal performance, carcass and meat quality. J. Anim. Sci. 2013, 91, 1454-1467.

78. Neel, J.P.; Fontenot, J.P.; Clapham, W.M.; Duckett, S.K.; Felton, E.E.; Scaglia, G.; Bryan, W.B. Effects of winter stocker growth rate and finishing system on: I. Animal performance and carcass characteristics. J. Anim. Sci. 2007, 85, 2012-2018.

79. Scaglia, G.; Fontenot, J.P.; Swecker, W.S.; Corl, B.A.; Duckett, S.K.; Boland, H.T.; Smith, R.; Abaye, A.O. Performance, carcass, and meat characteristics of beef steers finished on 2 different forages or on a high-concentrate diet. Prof. Anim. Sci. 2012, 28, 194-203.

80. Bennett, L.L.; Hammond, A.C.; Williams, M.J.; Kunkle, W.E.; Johnson, D.D.; Preston, R.L.; Miller, M.F. Performance, carcass yield, and carcass quality characteristics of steers finished on rhizoma peanut (Arachis glabrata)-tropical grass pasture or concentrate. J. Anim. Sci. 1995, 73, 1881-1887.

81. Hedrick, H.B.; Paterson, J.A.; Matches, A.G.; Thomas, J.D.; Morrow, R.E.; Stringer, W.C.; Lipsey, R.J. Carcass and palatability characteristics of beef produced on pasture, corn silage and corn grain. J. Anim. Sci. 1983, 57, 791-801.

82. Muir, P.D.; Deaker, J.M.; Bown, M.D. Effects of forage- and grain-based feeding systems on beef quality: A review. New Zeal. J Agr. Sci. 1998, 41, 623-635.

83. Scollan, N.; Hocquette, J.F.; Nuernberg, K.; Dannenberger, D.; Richardson, I.; Moloney, A. Innovations in beef production systems that enhance the nutritional and health value of beef lipids and their relationship with meat quality. Meat Sci. 2006, 74, 17-33.

84. Duckett, S.K.; Neel, J.P.; Fontenot, J.P.; Clapham, W.M. Effects of winter stocker growth rate and finishing system on: III. Tissue proximate, fatty acid, vitamin, and cholesterol content. J. Anim. Sci. 2009, 87, 2961-2970.

85. Noci, F.; Monahan, F.J.; French, P.; Moloney, A.P. The fatty acid composition of muscle fat and subcutaneous adipose tissue of pasture-fed beef heifers: Influence of the duration of grazing. J. Anim. Sci. 2005, 83, 1167-1178.

86. Gilmore, L.A.; Walzem, R.L.; Crouse, S.F.; Smith, D.R.; Adams, T.H.; Vaidyanathan, V.; Cao, X.; Smith, S.B. Consumption of high-oleic acid ground beef increases HDL-cholesterol concentration but both high- and low-oleic acid ground beef decrease HDL particle diameter in normocholesterolemic men. J. Nutr. 2011, 141, 1188-1194. 
87. Kris-Etherton, P.M.; Pearson, T.A.; Wan, Y.; Hargrove, R.L.; Moriarty, K.; Fishell, V.; Etherton, T.D. High-monounsaturated fatty acid diets lower both plasma cholesterol and triacylglycerol concentrations. Am. J. Clin. Nutr. 1999, 70, 1009-1015.

88. Chait, A.; Brazg, R.L.; Tribble, D.L.; Krauss, R.M. Susceptibility of small, dense, low-density lipoproteins to oxidative modification in subjects with the atherogenic lipoprotein phenotype, pattern B. Am. J. Med. 1993, 94, 350-356.

89. Kouba, M. Quality of organic animal products. Livest. Prod. Sci. 2003, 80, 33-40.

90. Caroprese, M.; Marzano, A.; Marino, R.; Gliatta, G.; Muscio, A.; Sevi, A. Flaxseed supplementation improves fatty acid profile of cow milk. J. Dairy Sci. 2010, 93, 2580-2588.

91. Kronberg, S.L.; Scholljegerdes, E.J.; Leper, A.N.; Berg, E.P. The effect of flaxseed supplementation on growth, carcass characteristics, fatty acid profile, retail shelf life, and sensory characteristics of beef from steers finished on grasslands of the northern Great Plains. J. Anim. Sci. 2011, 89, 2892-2903.

92. Donovan, D.C.; Schingoethe, D.J.; Baer, R.J.; Ryali, J.; Hippen, A.R.; Franklin, S.T. Influence of dietary fish oil on conjugated linoleic acid and other fatty adids in milk fat from lactating dairy cows. J. Dairy Sci. 2000, 83, 2620-2628.

93. Olesen, J.E.; Schelde, K.; Weiske, A.; Weisbjerg, M.R.; Asman, W.A.H.; Djurhuus, J. Modelling greenhouse gas emissions from European conventional and organic dairy farms. Agr. Ecosyst. Environ. 2006, 112, 207-220.

94. Thomassen, M.A.; van Calker, K.J.; Smits, M.C.J.; Iepema, G.L.; de Boer, I.J.M. Life cycle assessment of conventional and organic milk production in the Netherlands. Agr. Syst. 2008, 96, 95-107.

95. Lynch, D.; MacRae, R.; Martin, R. The carbon and global warming potential impacts of organic farming: Does it have a significant role in an energy constrained world? Sustainability 2011, 3, 322-362.

96. Capper, J.L.; Castaneda-Gutierrez, E.; Cady, R.A.; Bauman, D.E. The environmental impact of recombinant bovine somatotropin (rbST) use in dairy production. Proc. Natl. Acad. Sci. USA 2008, 105, 9668-9673.

97. FAO. Greenhouse Gas Emissions from the Dairy Sector: A Life Cycle Assessment; Food and Agiculture Organization of the United Nations, Animal Production and Health Division: Rome, Italy, 2010.

98. United States Department of Agriculture, Economic Research Service (USDA-ERS). Farm Milk Production. Available online: http://www.ers.usda.gov/topics/animal-products/dairy/background.aspx (accessed on 24 March 2013).

99. Schultz, M. Organic Dairy Profile; Agricultural Marketing Resource Center: Washington, DC, USA, 2013.

100. Peters, G.M.; Rowley, H.V.; Wiedemann, S.; Tucker, R.; Short, M.D.; Schulz, M. Red meat production in Australia: Life cycle assessment and comparison with overseas studies. Envir. Sci. Tech. 2010, 44, 1327-1332.

101. Crosson, P.; Shalloo, L.; O’Brien, D.; Lanigan, G.J.; Foley, P.A.; Boland, T.M.; Kenny, D.A. A review of whole farm systems models of greenhouse gas emissions from beef and dairy cattle production systems. Anim. Feed Sci. Tech. 2011, 166-167, 29-45.

102. Kim, S.; Dale, B.E. Cumulative energy and global warming impact from the production of biomass for biobased products. J. Ind. Ecol. 2004, 7, 147-162. 
103. CAST. Carbon Sequestration and Greenhouse Gas Fluxes in Agriculture: Challenges and Opportunities; Task Force Report No. 142; Council for Agricultural Science and Technology: Ames, IA, USA, 2011.

104. Paustian, K.; Antle, J.M.; Sheehan, J.; Paul, E.A. Agriculture's Role in Greenhouse Gas Mitigation; Pew Center on Global Climate Change: Arlington, VA, USA, 2006.

105. Follett, R.F.; Reed, D.A. Soil carbon sequestration in grazing lands: Societal benefits and policy implications. Rangel Ecol. Manag. 2010, 63, 4-15.

106. Sayre, N.F.; Carlisle, L.; Huntsinger, L.; Fisher, G.; Shattuck, A. The role of rangelands in diversified farming systems: Innovations, obstacles, and opportunities in the USA. Ecol. Soc. 2012, 17, 43 .

107. Greene, C. Data Track the Expansion of International and U.S. Organic Farming. Amber Waves 2007, 5, 36-37.

108. White, S.L.; Benson, G.A.; Washburn, S.P.; Green, J.T. Milk production and economic measures in confinement or pasture systems using seasonally calved Holstein and Jersey cows. J. Dairy Sci. 2002, $85,95-104$.

109. Dartt, B.A.; Lloyd, J.W.; Radke, B.R.; Black, J.R.; Baneene, J.B. A comparison of profitability and economic efficiencies between management-intensive grazing and conventionally managed dairies in Michigan. J. Dairy Sci. 1999, 82, 2412-2420.

110. Hanson, G.D.; Cunningham, L.C.; Morehart, M.J.; Parsons, R.L. Profitability of moderate intensive grazing of dairy cows in the Northeast. J. Dairy Sci. 1998, 81, 821-829.

111. Hanson, J.C.; Johnson, D.M.; Lichtenberg, E.; Minegishi, K. Competitiveness of managementintensive grazing dairies in the mid-Atlantic region from 1995 to 2009. J. Dairy Sci. 2013, 96, 1894-1904.

112. Parker, W.J.; Muller, L.D.; Buckmaster, D.R. Management and economic implications of intensive grazing on dairy farms in the northeastern states. J. Dairy Sci. 1992, 75, 2587-2597.

113. McBride, W.D.; Greene, C. Characteristics, Costs, and Issues for Organic Dairy Farming; Research Report Number 82; United States Department of Agriculture, Economic: Washington, DC, USA, 2009.

114. Berentsen, P.B.; Kovacs, K.; van Asseldonk, M.A. Comparing risk in conventional and organic dairy farming in the Netherlands: an empirical analysis. J. Dairy Sci. 2012, 95, 3803-3811.

115. Lund, V. Natural living - a precondition for animal welfare in organic farming. Livest. Sci. 2006, 100, 71-83.

116. Bocquier, F.; Gonzalez-Garcia, E. Sustainability of ruminant agriculture in the new context: Feeding strategies and features of animal adaptability into the necessary holistic approach. Animal 2010, 4, 1258-1273.

117. Hodgson, J. Grazing Management: Science into Practice; Longman Scientific and Technical: Harlow, Essex, UK, 1990.

118. Dillon, P.; Hennessy, T.; Shalloo, L.; Thorne, F.; Horan, B. Future outlook for the Irish dairy industry: A study of international competitiveness, influence of international trade reform and requirement for change. Int. J. Dairy Technol. 2008, 61, 16-29.

119. Peyraud, J.L.; Delagarde, R. Managing variations in dairy cow nutrient supply under grazing. Animal 2013, 7, 57-67. 
120. Butler, L.J. The economics of organic milk production in California: A comparison with conventional costs. Am. J. Alternative Agr. 2002, 17, 83-91.

121. Rotz, C.A.; Kamphuis, G.H.; Karsten, H.D.; Weaver, R.D. Organic dairy production systems in Pennsylvania: A case study evaluation. J. Dairy Sci. 2007, 90, 3961-3979.

122. Rouquette, F.M.; Redmon, L.A.; Aiken, G.E.; Hill, G.M.; Sollenberger, L.E.; Andrae, J. ASAS Centennial Paper: Future needs of research and extension in forage utilization. J. Anim. Sci. 2009, 87, 438-446.

123. Younie, D. An organic approach to meat production. Food Sci. Technol. Today 1992, 6, 163-166.

124. Fernández, M.I.; Woodward, B.W. Comparison of conventional and organic beef production systems I. Feedlot performance and production costs. Livest. Prod. Sci. 1999, 61, 213-223.

125. Lewis, J.M.; Klopfenstein, T.J.; Pfeiffer, G.A.; Stock, R.A. An economic evaluation of the differences between intensive and extensive beef production systems. J. Anim. Sci. 1990, 68, 2506-2516.

126. Reichl, R. Michael Pollan and Ruth Reichl hash out the food revolution. Smithsonian 2013, 44, 74-83.

127. Papendick, R.I.; Elliot, L.F.; Dalgren, R.B. Environmental consequences of modern production agriculture: How can alternative agriculture address these concerns? Am. J. Alternative Agr. 1986, 1, 3-10.

128. Lasley, P.; Hoiberg, E.; Bultena, G. Is sustainable agriculture an elixir for rural communities? Am. J. Alternative Agr. 1993, 8, 133-139.

129. Realini, C.E.; Duckett, S.K.; Brito, G.W.; Dalla Rizza, M.; de Mattos, D. Effect of pasture $v s$. concentrate feeding with or without antioxidants on carcass characteristics, fatty acid composition, and quality of Uruguayan beef. Meat Sci. 2004, 66, 567-577.

(C) 2013 by the authors; licensee MDPI, Basel, Switzerland. This article is an open access article distributed under the terms and conditions of the Creative Commons Attribution license (http://creativecommons.org/licenses/by/3.0/). 